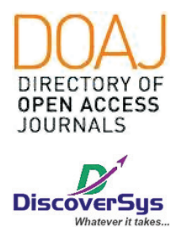

Published by DiscoverSys

\title{
Hubungan asupan serat dengan angka kejadian kanker kolorektal di RSUP Sanglah Denpasar tahun 2016 - 2017
}

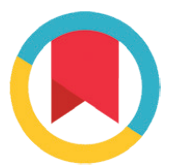

CrossMark

\author{
Rani Pradnya Swari, ${ }^{*}$ Made Agus Dwianthara Sueta, ${ }^{2}$ Made Suka Adnyana ${ }^{2}$
}

\section{ABSTRACT}

Background: Colorectal cancer is one of the most common cancer in Indonesia. The etiology of colorectal cancer is still unknown, but many risk factors believed may causing colorectal cancer, one of them is fiber intake of foods consumed every day like vegetables, fruits, and peanuts. There is an instrument that can be used to assess fiber intake per day. Aim: The study aimed to know how the correlation between fiber intake and colorectal cancer patient are in Sanglah General Hospital. Method: The design is a case-control analytic study, obtained total of 104 samples that divided into case group (52 samples) and control group (52 samples), in which secondary data with medical record data and also primary data with questionnaire are collected. Data were analyzed using the SPSS program.

Result: Of the 104 samples that divided into case group and control group with 1:1 ratio, patients who diagnosed with colorectal cancer had a history of low fiber intake higher 6.75 times than peoples who not diagnosed with colorectal cancer $(0 \mathrm{R}=6.75 ; 95 \% \mathrm{Cl} 2.85-15.96$; $\mathrm{P}<0.001)$.

Conclusion: Patients who diagnosed with colorectal cancer had a history of low fiber intake per day higher 6.75 times than samples which did not diagnose with colorectal cancer.
1Program Studi Pendidikan Dokter Fakultas Kedokteran Universitas Udayana

${ }^{2}$ Bagian/SMF Bedah Digestif Fakultas Kedokteran Universitas Udayana, RSUP Sanglah

${ }^{*}$ Correspondence to: Rani Pradnya Swari, Program Studi Pendidikan Dokter Fakultas Kedokteran Universitas Udayana ranipradnya97@gmail.com

Diterima: $19-04-2018$

Disetujui: 08-08-2018

Diterbitkan: 01-08-2019
Keywords: fiber intake, colorectal cancer, oncology

Cite This Article: Swari, R.P., Sueta, M.A.D., Adnyana, M.S. 2019. Hubungan asupan serat dengan angka kejadian kanker kolorektal di RSUP Sanglah Denpasar tahun 2016 - 2017. Intisari Sains Medis 10(2): 168-171. D0l: 10.15562/ism.v10i2.262
Latar belakang : Kanker kolorektal merupakan salah satu dari kejadian kanker tersering di Indonesia. Penyebab dari kanker kolorektal sendiri sampai saat ini belum diketahui secara pasti, tetapi banyak faktor risiko yang dipercaya dapat menyebabkan kanker kolorektal, salah satunya adalah jumlah asupan serat dari sumber makanan sehari-hari seperti sayur, buah, dan kacang-kacangan. Terdapat instrumen berupa kuisioner yang dapat digunakan untuk menilai kecukupan asupan serat.

Tujuan: Untuk mengetahui bagaimana hubungan asupan serat terhadap angka kejadian kanker kolorektal pada pasien RSUP Sanglah. Metode : Penelitan ini merupakan penelitian analitik kasus-kontrol, diperoleh total 104 sampel yang dibagi menjadi kelompok kasus dan kontrol. Kelompok kasus adalah pasien yang terdiagnosis kanker kolorektal (52 orang) dan kelompok kontrol adalah mahasiswa kedokteran yang tidak terdiagnosis kanker kolorektal (52 orang). Data ini diambil secara sekunder dengan melihat rekam medis pasien dan juga diambil data secara primer dengan melakukan wawancara kuisioner. Data dianalisis dengan menggunakan program SPSS.

Hasil : Dari total subjek peneltian yang berjumlah 104 orang yang dibagi menjadi kelompok kasus dan kontrol dengan perbandingan 1:1, ditemukan bahwa pasien yang terdiagnosis kanker kolorektal memiliki riwayat kurang konsumsi serat lebih tinggi 6,75 kali dibandingkan orang yang tidak terdiagnosis kanker kolorektal $(O R=6,75 ; 95 \% \mathrm{Cl}$ 2,85-15,96; $\mathrm{P}<0.001)$.

Simpulan : Pasien yang terdiagnosis kanker kolorektal memiliki riwayat kurang asupan serat per hari lebih tinggi 6,75 kali dibandingkan dengan orang yang tidak terdiagnosis kanker kolorektal.

\section{Kata kunci : Asupan serat, kanker kolorektal, onkologi} Cite Pasal Ini: Swari, R.P., Sueta, M.A.D., Adnyana, M.S. 2019. Hubungan asupan serat dengan angka kejadian kanker kolorektal di RSUP Sanglah Denpasar tahun 2016 - 2017. Intisari Sains Medis 10(2): 168-171. D0I: 10.15562/ism.v10i2.262

\section{PENDAHULUAN}

Kanker kolorektal merupakan kanker tersering nomor tiga di dunia setelah kanker paru-paru dan kanker payudara dengan insiden sebanyak 1.4 juta kasus dengan 694.000 kematian. Pada wanita, kanker kolorektal merupakan kanker tersering kedua setelah kanker payudara dengan jumlah insiden kasus 614.000 atau 9.2\% dari total kasus kanker, sedangkan pada pria menjadi kanker 
tersering nomor tiga setelah kanker paru-paru dan prostat dengan total insiden kasus 746.000 atau seki$\operatorname{tar} 10 \%$ dari semua insiden kasus kanker. Hampir 55\% kejadian kanker kolorektal terjadi pada negara maju dengan presentase insiden tertinggi terjadi di Australia dan terendah di Afrika barat, akan tetapi jumlah kematian yang ditimbulkan oleh kanker kolorektal lebih banyak yaitu sekitar 52\% kematian kanker kolorektal terjadi pada negara berkembang. ${ }^{1}$ Kemungkinan seorang wanita menderita kanker kolorektal adalah $4.7 \%$ dan pria $5.0 \%$ sedangkan mortalitas kanker kolorektal 30-40\% lebih tinggi daripada perempuan. ${ }^{2}$ Di Indonesia, berdasarkan data dari RS.Dharmais Jakarta pada tahun 20102013, lima besar kejadian kanker tersering adalah payudara, paru, serviks, ovarium dan kolorektal. ${ }^{3}$ Di Bali terurama di RSUP Sanglah Denpasar, pada tahun 2009-2013 terdapat sebanyak 97 pasien kanker kolorektal dengan $70.1 \%$ nya berusia di bawah 60 tahun dan $29.9 \%$ berusia diatas 60 tahun dan jenis kanker kolorektal terseringnya adalah jenis adenokarsinoma. ${ }^{4}$

Kanker kororektal didefinisikan sebagai perkembangan sel neoplasia pada kolon atau rektum yang diakibatkan dari perkembangan sel yang tidak normal yang menginvasi dan menyebar pada bagian dari usus besar. Kanker kolorektal biasanya terdiagnosis setelah munculnya gejala pendarahaan pada feses pada kebanyakan pasien. Selain pendarahan pada feses, pasien kerap kali mengalami nyeri abdomen, anemia defisiensi besi yang tidak dapat dilacak penyebabnya serta perubahan kebiasaan buang air besar. Literatur mengatakan bahwa seki$\operatorname{tar} 86 \%$ pasien kanker kolorektal terdiagnosis di bawah umur 50 tahun. Pasien yang asimptomatik mengetahui dirinya terkena kanker kolorektal pada saat melakukan skrining rutin. Beberapa pasien juga ada yang terdiagnosis saat keadaan gawat darurat akibat adanya obstruksi usus, peritonitis dan pendarahan gastrointestinal. ${ }^{5}$

Kanker kolorektal merupakan kanker yang disebabkan oleh berbagai faktor/ multifaktorial. Beberapa faktor yang dapat meningkatkan resiko terhadap kejadian kanker kolorektal adalah genetik, jenis kelamin, dan faktor resiko yang masih dapat diintervensi oleh masing-masing individu seperti merokok, mengkonsumsi alkohol berlebihan, kurang berolahraga, obesitas serta pola makan yang dimiliki masing-masing individu. ${ }^{5}$

Hal yang menarik dari kanker kolorektal adalah kanker ini dipengaruhi oleh apa yang kita makan sehari-hari. Beberapa makanan bersifat protektif terhadap kanker kolorektal, namun beberapa makanan justru dapat memicu terjadinya kanker kolorektal. Sudah banyak literatur yang membahas mengenai pengaruh diet terhadap kejadian kanker kolorektal namun hasilnya masih inkonsisten karna beberapa peneliti menemukan tidak adanya hubungan yang signifikan antara diet dan kejadian kanker kolorektal. Peneliti yang menemukan adanya korelasi signifikan terhadap diet dan kejadian kanker kolorektal berspekulasi bahwa makanan yang kita makan akan mempengaruhi keberagaman mikrobiota yang berada di dalam usus yang nantinya akan mempengaruhi proses terbentuknya kanker. Adapula yang berpendapat bahwa makanan yang dikonsumsi dapat memepengaruhi proses signaling gen pada tingkat selular dan mempengaruhi kejadian kanker kolorektal. ${ }^{6}$

\section{METODE}

Penelitian ini merupakan penelitian analitik dengan rancangan penelitian unmatched paired case control sehingga dapat mengetahui hubungan asupan makanan berserat dengan kanker kolorektal pada pasien kanker kolorektal di RSUP Sanglah, Denpasar. Populasi target penelitian ini dibagi menjadi dua kelompok, yaitu kelompok kasus yang merupakan pasien dengan kanker kolorektal di RSUP Sanglah dari tahun 2016-2017 dan kelompok control yang merupakan mahasiswa kedokteran Universitas Udayana. Pengambilan sampel dilakukan dengan cara non-probability sampling dengan menggunakan teknik quota sampling dengan besar sampel 52 orang untuk kelompok kasus dan 52 orang untuk kelompok kontrol. Data karakteristik didapat melalui rekam medis RSUP Sanglah dan kuisioner data outcome berdasarkan pedoman wawancara. Data yang telah terkumpul dianalisis dengan statistical packagae for the social sciences (SPSS) versi 20, dimana akan dilakukan uji hipotesis terhadap kelompok kasus dan kelompok kontrol dengan menggunakan uji Chi Square.

\section{HASIL}

Jumlah sampel dalam penelitian ini adalah 104 orang, dimana 52 orang merupakan pasien di RSUP Sanglah yang terdiangnosis kanker kolorektal dan 52 orang lainnya merupakan mahasiswa kedokteran yang tidak terdiagnosis kanker kolorektal. Sebagian besar sampel berjenis kelamin perempuan $(67,3 \%)$ dan lebih dari setengahnya mengkonsumsi serat $\leq 21$ gram setiap harinya.

Hasil dari Tabel $2 \times 2$ antara asupan serat dan kejadian kanker kolorektal menunjukkan bahwa sebanyak 39 pasien dengan kanker kolorektal mengkonsumsi asupan rendah serat setiap harinya, sedangkan 13 pasien kanker kolorektal lainnya mengkonsumsi asupan tinggi serat setiap harinya. Sebaliknya, sebanyak 36 orang yang tidak 
Tabel 1 Karakteristik subjek penelitian

\begin{tabular}{ll}
\hline Karakteristik Pasien & $\mathbf{n}(\%)$ \\
\hline Jenis kelamin & \\
Laki-laki & $34(32,7)$ \\
$\quad$ Perempuan & $70(67,3)$ \\
Asupan Serat (per hari) & \\
$\quad \leq 21$ gram & $55(52,9)$ \\
$>21$ gram & $49(47,1)$
\end{tabular}

Tabel 2 Hasil Tabel $\mathbf{2 \times 2}$ asupan serat dan kanker kolorektal

\begin{tabular}{lcc}
\hline Kanker Kolorek- tal & Tidak Kanker \\
Asupan Serat & Kanker Kolorektal (+) & $\begin{array}{c}\text { Kolorektal (-) } \\
\text { Koltal }\end{array}$ \\
\hline Rendah Serat (+) & 39 & 16 \\
Tinggi Serat (-) & 13 & 36 \\
\hline
\end{tabular}

Tabel 3 Hasil analisa bivariat pengaruh asupan serat terhadap angka kejadian kanker kolorektal

\begin{tabular}{lccccc}
\hline Karakteristik & $\begin{array}{c}\text { Kasus (N=52) } \\
\mathbf{N}(\mathbf{\%})\end{array}$ & $\begin{array}{c}\text { Kontrol } \\
\mathbf{( N = 5 2 )}\end{array}$ & $\mathbf{p}$ & $\mathbf{O R}$ & $\mathbf{9 5 \%} \mathbf{~ c ~}$ \\
\hline Asupan Serat (per hari) & & & 0,000 & 6,75 & $2,85-15,96$ \\
$\leq 21$ gram & $39(75,0 \%)$ & $16(30,8 \%)$ & & & \\
$>21$ gram & $13(25,0 \%)$ & $36(69,2 \%)$ & & & \\
\hline
\end{tabular}

terdiagnosis kanker kolorektal mengkonsumsi asupan tinggi serat setiap hari, sedangkan 16 orang mengkonsumsi asupan rendah serat setiap harinya.

Analisis variable asupan serat terhadap angka kejadian kanker kolorektal ditentukan berdasarkan nilai p, nilai odd ratio (OR), dan 95\% CI dari OR yang menggunakan uji chi square. Hasil analisis menunjukkan bahwa pasien yang terdiagnosis kanker kolorektal memiliki riwayat kurang konsumsi serat lebih tinggi 6.75 kali dibandingkan orang yang tidak terdiagnosis kanker kolorektal $(\mathrm{OR}=6,75 ; 95 \%$ CI 2,85-15,96; $\mathrm{p}<0,001)$.

\section{DISKUSI}

Hasil penelitian ini menunjukkan bahwa pada pasien di RSUP Sanglah yang terdiagnosis kanker kolorektal, cenderung kurang mengkonsumsi serat setiap harinya jika dibandingkan orang yang tidak terdiagnosis kanker kolorektal. Hasil penelitian ini sesuai dengan hasil penelitian yang dilakukan di Negara lain. Penelitian yang dilakukan oleh Godos (2016) menyebutkan bahwa berdasarkan bukti epidemiologi, bahan makanan seperti sayur, buah, dangan utuh dapat menurunkan risiko kanker kolorektal. Hal ini mungkin diakibatkan oleh kandungan serat, PUFA, polifenol, dan vitamin yang memiliki peran untuk mencegan karsinogenesis kolorektal. ${ }^{7}$

Kuzmann (2015) pada penelitian yang dilakukan di United States disebutkan bahwa pada individu yang mengkonsumsi serat lebih tinggi terdapat penurunan risiko kanker kolorektal secara signifikan. Penelitian ini juga menyebutkan bahwa hubungan protektif asupan serat lebih kuat pada individu yang mengkonsumsi daging olahan diatas rata-rata per hari dibandingkan yang mengkonsumsi daging olahan dibawah rata-rata per hari. ${ }^{8}$

Sedangkan Murphy (2012) pada penelitiannya di Eropa diketahui bahwa terdapat penurunan signfikan sebesar $11 \%$ risiko terjadinya kanker kolorektal pada sampel yang mengkonsumsi serat 10 gram/hari. Hasil yang didapatkan mirip dengan penelitian dari Baena (2015) yang menyebutkan bahwa konsumsi serat sebanyak 21-38 gram sehari memiliki efek protektif terhadap kanker kolorektal. ${ }^{9}$

Namun disisi lain Bakken (2015), pada penelitiannya menyebutkan tidak ada hubungan antara jumlah asupan serat per hari dengan angka kejadian kanker kolorektal. Bakken meneliti asupan serat dengan memberikan sarapan gandum utuh kepada sampel penelitian yang kemudian diamati dengan studi kohort. Gandum utuh merupakan salah satu bahan makanan yang mengandung serat tinggi. ${ }^{10}$

\section{SIMPULAN}

Asupan serat merupakan faktor yang berperan signifikan dalam menurunkan risiko terjadinya kanker kolorektal pada pasien di RSUP Sanglah. Pada pasien dengan kanker kolorektal, riwayat kurang asupan serat lebih tinggi 6,75 kali dibandingkan dengan pasien tanpa kanker kolorektal.

\section{DAFTAR PUSTAKA}

1. Ferlay Jacques, Soerjomataram Isabelle, Dikshit Rajesh, $\mathrm{dkk}$. Cancer incidence and mortality worldwide: sources, methods and major patterns in Globocan. International Journal of Cancer. 2014; 359-386.

2. Siegel Rebecca, De Satins Carol, Jemal Ahmedin. Colorectal Cancer Statistic 2014. A Cancer Journal for Clinicians; 2014.

3. Kemenkes RI. Infodatin Kanker. Pusat Data dan Informasi Kemenkes RI; 2013.

4. Gamayanti K.A, Maliawan S, Kawiyana K.S. Karakteristik Histologis, Stadium klinis dan Terapi Kanker Kolon pada pasien lanjut usia di RSUP Sanglah. SMF Bedah RSUP Sanglah; 2014.

5. Young Joanne, Win Aung, Rosty Christope, dkk. Rising Incidence of Early Onset Colorectal cancer in Australia over Two Decades: Report and Review. Journal of Gastroenterology and Hepatology; 2014.

6. Azeem Salman, Gillani Syed, Shidiqui Ammar, dkk. Diet and Colorectal Cancer Risk in Asia-a Systematic Review. Asian Pac J Cancer Prev. 2015; 16(13): 5389-96. 
7. Godos, Bella, Torissi, dkk. Dietary Patterns and Risk of colorectal cancer: a Systematic Review and meta-analysis of observational study. The official journal of The British Dietic Association; 2016.

8. Kunzmann Andrew, Coleman Helen, Huang Wen, dkk. Dietary fiber intake and risk of colorectal cancer and incident and recurrent adenoma in the Prostate, Lung, Colorectal and Ovarian Cancer Screening Trial. Am J Clin Nutr; 2015.

9. Murphy N, Norat T, Ferrari P, dkk. Dietary Fibre Intake and Risks of Cancer Colon and Rectum in the European Prospective Investigation into Cancer and Nutrition (EPIC). Public Library of Sciencer; 2012.
10. Bakken Toril, Braaten Tonje, Olsen Anja, dkk. Consumption of Whole Grain Bread and Risk of Colorectal Cancer among Norwegian Women (The Nowac Study). Nutrients; 2015.

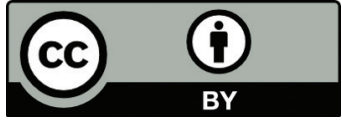

This work is licensed under a Creative Commons Attribution 